International Journal of Islamic Educational Psychology

Vol. 2, No. 1, June 2021

DOI: https://doi.org/10.18196/ijiep.v1i2.11132

\title{
Spiritualization of Child Education in the Qur'anic Sufism Perspective in the Covid-19 Era
}

\author{
${ }^{1}$ Muh. Mustakim*, ${ }^{1}$ Kana Safrina Rouzi, ${ }^{2}$ Tumin Tumin \\ 1 Universitas Alma Ata, Indonesia \\ 2Universitas Muhammadiyah Yogyakarta, Indonesia
}

*Corresponding email: muh.mustakim@almaata.ac.id

\section{ARTICLE INFO}

Article history

Received, 11/02/2021

Revised, 06/04/2021

Accepted, 12/04/2021

Keywords

Children's education

Qur'anic

Spiritualization

Sufism

\begin{abstract}
The COVID-19 pandemic has implications for changing the attitudes and behavior of the world community, including in the field of education. The Indonesian government, in this case, has decided to study from home (BDR) for schools to universities in addition to the work from home (WFH) policy. BDR challenges have both advantages and disadvantages. Among the weaknesses that need to be watched out for is the burnout of children in online learning from home, which cannot be denied because similar conditions are also experienced by parents, which erode the enthusiasm for learning to spirituality in the family. Therefore, this paper examines how to reconstruct the spiritualization of education for children in families amid COVID-19. This qualitative research used a descriptive approach, describing the data obtained from the interpretation of the term "tazkiyah" in the Qur'an and verses related to children's education to be contextualized into building the spiritualization concept of children's education in the perspective of Qur'anic Sufism. As part of the literature research, the data analysis adopted Gadamer's hermeneutics developed by Fakhrudin Faiz that hermeneutics revolves around text, context, and contextualization. The results showed that parents have a major role in children's education amid COVID-19 as the prominent educators in the family. These findings corroborate the opinions of Comenius, Nasih Ulwan, Abdurrahaman An-Nahlawi, and Ki Hajar Dewantara about the importance of family education. The spiritualization of children's education in the perspective of Quranic Sufism integrates the three theologies in religion as proposed by Barbour, namely the theology of revelation, natural theology, and religious experience. Therefore, the spiritualization of children's education is a necessity.
\end{abstract}

This is an open access article under the CC-BY-SA license.

\section{Citation:}

Mustakim, M., Rouzi, K.S., \& Tumin, T. (2021). Spiritualization of child education in the qur'anic sufism perspective in the Covid-19 era. International Journal of Islamic Educational Psychology, 2(1), 53-66. DOI: https:/ / doi.org/10.18196/ijiep.v1i2.11132 
Mustakim, Rouzi \& Tumin | Spiritualization of Child Education in the Qur'anic Sufism Perspective in the Covid-19 Era

\section{INTRODUCTION}

COVID-19 is a global pandemic experienced by almost all countries in the world. The virus originated in Wuhan (a state territory), China, has grown rapidly since the end of 2019, and has continued to spread massively to other regions, even between countries in early 2020 (Jannah, 2020). In Indonesia, the virus was first discovered in Depok, West Java, as announced by Indonesian government authorities. Despite the pros and cons in responding to it, the Indonesian government is getting serious about dealing with the virus after one of the "Indonesia Maju [Advanced Indonesia]" ministers formed by President Jokowi-Ma'ruf, who won the 2019 election, was confirmed positive for COVID19 (Indriya, 2020; Djalante et al., 2020).

Because of the many positive confirmed cases of COVID-19 found every day, the government announced the COVID-19 pandemic as a national pandemic, especially after WHO announced COVID-19 as a global pandemic (Kannan et al., 2020; Momtazmanesh et al., 2020; Pavone, 2020). The COVID-19 pandemic and its handling policies have implications for the lives of Indonesians, both in the health, economy, and education sectors. Among the phenomenal policies for the Indonesian nation is work from home and study from home (BDR). Moreover, there is a regional quarantine policy (lockdown) in several regions in Indonesia (Rohman, 2020; Herliandry et al., 2020; Ilmi et al., 2020).

Meanwhile, schools are required to learn from home, which is a comprehensive policy for all schools in Indonesia. In this case, children have much time at home with their parents. Likewise, parents have much time accompanying children to learn from home. Thus, it raises separate anxiety; can parents play a role as teachers for their children and become a driving force for learning for their children, as do teachers in schools? It is not easy for parents to take the role of educators. In fact, if examined further, children's education in Islam is the parents' role and responsibility (Nafisah et al., 2020; Siahaan, 2020; Suharini et al., 2020; Suhendro, 2020; Sumantyo, 2020).

The theory of al-umm madrasatul 'ula emphasizes the vital role of a mother as the primary school for her children (Muhtadi, 2017; Parhan, 2020), although, in its development, this role has shifted because the mother has a dual role, namely working, especially in the modern world (Lailiyah et al., 2020; Yasin, 2018). Therefore, the implications of studying/schooling from home are a big challenge for parents for their children's education. If it is not done well, it may negatively impact the children's education process (Kamil, 2020; Mufaziah et al., 2020). In the Qur'an, O you who have believed, protect yourselves and your families from a Fire whose fuel is people and stones, over which are [appointed] angels, harsh and severe; they do not disobey Allah in what He commands them but do what they are commanded (QS. At-Tahrim: 6).

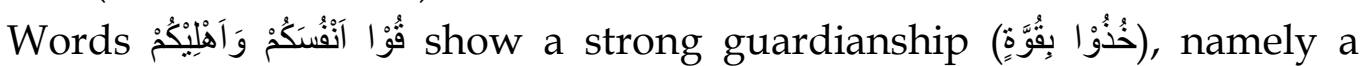
maximum effort so that a person, his children, and his family are saved from all badness, both the world and the hereafter. The description above reveals the urgency of the parents' essential roles in their children's education. One of the 
Mustakim, Rouzi \& Tumin | Spiritualization of Child Education in the Qur'anic Sufism Perspective in the Covid-19 Era

ways to achieve this challenging task is through the spiritualization of Qur'anic education, which is the spiritualization of education built on the inspiration and understanding of the Qur'an. Although it is new, the theory about the spiritualization of Qur'anic education introduced by Muh Mustakim (2020) can be considered as an alternative at this uncertain time.

Research on the spiritualization of the Qur'an as the authors describe above is like the research of Mustakim (2020), suggesting the spiritualization of Qur'anic education, Muhtadi (2017), and Parhan (2020) regarding the importance of family education, namely the parents' roles, especially the mother's role. It is in line with Nafisah et al. (2020), Siahaan (2020), Suharini et al., (2020), Suhendro (2020), and Sumantyo (2020). In this paper, specifically, the authors develop the spiritualization of education in terms of Qur'anic Sufism and its implications during the pandemic, especially in children's education. Rohman (2020), Herliandry et al. (2020), and Ilmi et al. (2020) have researched the challenges faced in implementing learning during the COVID-19 era; this further reinforces the importance of spiritualization in the learning process. Therefore, the authors try to reveal how the spiritualization of children's education from the perspective of Qur'anic Sufism during the COVID-19 era.

\section{METHODS}

This paper is the result of qualitative research using a descriptive approach. The term tazkiyah is alleged to represent the spiritualization conception of education based on the Qur'an. To find "sign" messages and impressions of the meaning of the tazkiyah term in the Al-Qur'an, a data analysis technique is needed, considered capable of exploring and then reconstructing into a complete concept. Thus, this study adopted hermeneutics (Darmawan, 2016; Wisri et al., 2016).

The meaning by adopting hermeneutic theory revolves around three main things: text, context, and contextualization. It is needed so that the meaning does not stop at the description of meaning but is far from it; namely, it can be contextualized in life to strengthen Islam as a way of life. In this study, the role of the writers was as a reader, receiver of meaning, and a second meaning giver (Sholihah, 2016; Irawan, 2020;)

The authors tried to be careful to get valid, objective, and accountable data. Thus, the authors also acted as a planner, data collector, data analyzer, and data interpreter as well as a research report maker to construct a meaning reconstruction based on the "sign" of the verses about the spiritualization of children's education in the perspective of Qur'anic Sufism into a complete concept building. The construction was then formulated into a conceptual guideline for implementation. The concept for implementation adopted the theory of the formulation of six pillars of Islamic education thought: teaching, the psychological basics of the learning process, understanding of students, teaching methods, teacher concepts, and preparation of individuals to participate in community life (Moleong, 2015; Akbar, 2015; Wardani, 2017). 
Mustakim, Rouzi \& Tumin | Spiritualization of Child Education in the Qur'anic Sufism Perspective in the Covid-19 Era

The data analysis in this study adopted Gadamer's hermeneutic theory. This theory suggests that to understand a text, four stages need to be passed. The first is the awareness of being influenced by history, in which tradition, culture, and life experiences will influence the text's interpretation. The second is influence with pre-understanding, namely the initial position (prior knowledge) to understand the text. The third is horizon assimilation, which merges two horizons of understanding: the horizon in the text and the horizon of the reader's understanding. The fourth is the application, namely the application (anwendung) of messages or teachings at a time when the text is interpreted (Bravo, 2018; Hanif, 2018; Prihananto, 2014).

The research steps consisted of (a) identifying the term tazkiyah in the AlQur'an; (b) reading, studying, and comparing the meaning of tazkiyah in the AlQur'an according to the mufassir; (c) narrating the inspiration of this meaning by adopting bayāni, irfānì, and burhānì as paradigms of thinking; (d) elaborating and exploring the implications of the verses' meaning as a building for the concept of education spiritualization in the perspective of the Qur'an; (e) constructing an educational spiritualization formulation based on the Qur'an inspired by the tazkiyah meaning, which was the research finding.

\section{RESULT AND DISCUSSION}

Studies on spiritualization have been carried out by many previous researchers. However, the study specifically on the children's education spiritualization based on Qur'anic Sufism, especially during the COVID-19 period, is relatively new. Therefore, the spiritualization of children's education and Sufism in the Qur'an is discussed first.

\section{Spiritualization of Child Education}

Referring to the Great Dictionary of the Indonesian Language, the term spiritualization can be seen from two-word formations. Spiritualization as a noun means soul; soul formation. Meanwhile, spiritualization as a form of verb leads to the meaning of a forming process; prepares individuals to carry out the psychiatric process of something (KBBI Arranging Team, 1995).

Photos defines spiritualization as animating values into attitudes and views of life. In the realm of Islamic scientific discourse, spiritualization is identified with "spirit" to lead people to achieve meaningful lives. The condition of ruhiyah has implications for one's dhahiriyah aspect; hence, a person's attitude and behavior reflect his inner condition. Spiritualization is closely related to the "formation" of personality. Some of these definitions are explained in many books on the spiritualization of Qur'anic education (Mustakim, 2020).

A spiritual perspective leads to an understanding that humans consist of physical (body) and feeling (soul); the two are inseparable. Physical and mental balance leads to peace, happiness, and physical and spiritual health. Many Muslim scientists develop spiritualization in the form of cognitive science 
Mustakim, Rouzi \& Tumin | Spiritualization of Child Education in the Qur'anic Sufism Perspective in the Covid-19 Era

studies, such as Ibn Sina, al-Ghazali, al-Muhasibi, Ibn Tufail, Ibn Khaldun, alMawardi, Said Hawa, Hasan Langgulung, and others (Hamzah et al., 2010).

One of the best ways to care for these ideal conditions is through education. The spiritualization of education based on the Qur'an is understood as a process of animating various educational values based on the understanding of the meaning of the Qur'an verses, both express and implied, to a person so that it becomes a view and attitude of life implemented in everyday life (Mustakim, 2020).

The stages of children's education in Islamic studies are divided into at least two stages: the stage before tamyiz and the stage of tamyiz age. Tamyiz means the ability to understand what is good and bad, something that is beneficial and harmful to children. More children's education requires handling and assistance that tends to listen more. Therefore, the educational model widely used by previous Muslim scientists for children was memorization, considering that the child has an excellent memory, so that the best memorization is at this golden age (Rohimin, 2017). Children growing towards maturity need the help and assistance of those around them. Among the most influential educational institutions for children is the family than other educational institutions.

\section{Tazkiyah as a Construction of Qur'anic Sufism Morals}

Qur'anic Sufism in this paper is intended as Sufism in the perspective of the Qur'an, namely the Sufism values, which are reconstructed from the understanding of the text of the Qur'an verses (Rahman, 2017; Tarmizi, 2017; Hasibuan, 2017; Mustakim et al., 2020). According to the authors, among the conceptions of Qur'anic Sufism related to the spiritualization of education (generally), it can be developed from an understasnding of the tazkiyah term in the al-Qur'an.

The term tazkiyah and its derivatives are repeated twenty-seven times in twenty verses spread across thirteen different surahs in the Qur'an. Various forms of derivation from the term tazkiyah are such as zakka, tuzakku, tuzakkihim, zuyakkuna, zuyakki, zuyakkihim, tazakka, yatazakka, yazzakka, azka, and zakiyya. Various forms of derivation from tazkiyah are classified into nine verses of makkiyah and 11 verses of maadaniyah (Maragustam, 2010; Nor, 2014). Al-Baqi specified the term tazkiyah and its derivation in the word zakka in Q.S. An-Nur: 21 and Q.S. Ash-Shams: 9. The word tuzakku is found in Q.S. An-Najm: 32. The word tuzakkihim is in Q.S. At-Taubah:103. The word zuyakkunna is in Q.S. An-Nisa: 49. Then, the word zuyakki is found twice, namely Q.S. An-Nisa': 49 and Q.S. AnNur: 21. The word zuyakkikum is in Q.S. Al-Baqarah: 151. The term zuyakkihim is found in five places: Q.S. Al-Baqarah 129 and 174, Q.S. Ali Imran: 77 and 164, and Q.S. Al-Jumu'ah: 2. The word tazakka is found in Q.S. Taha: 67, Q.S. Fatir: 18, Q.S. Al-A'la: 14, and Q.S. An-Nazi'at: 18. Meanwhile, the term yatazkka is found in two places: Q.S. Fatir: 18 and Q.S. Al-Lail: 18. The word yazzakka is found in Q.S. 'Abasa: 3 and 7. The word azka is found in four places: Q.S. Al-Baqarah: 232, Q.S. Al-Kahfi: 19, Q.S. An-Nur: 28 and 30. Another form is zakiyya, which is found in 
Mustakim, Rouzi \& Tumin | Spiritualization of Child Education in the Qur'anic Sufism Perspective in the Covid-19 Era

Q.S. Maryam: 19 and the word zakiyyatan in Q.S. Al-Kahfi: 74. The distribution of the term tazkiyah and its derivations is mentioned in the Qur'an 27 times in thirteen forms (Maragustam, 2010; Nor, 2014; Mustakim, 2020).

The distribution of the term tazkiyah, if examined in-depth, will lead to a vast and profound meaning, especially related to spiritualization. Among the meanings of tazkiyah in al-Qur'an are at-tathìr wa taqdīs, obedience and sincerity, ișläh̆ aś-śana' wal madh, tanmiyyah, and means khair. Al-Rāzī interprets the term tazkiyah into several: holy, clean, feeling free from sin, removing sins/dirt, and better. Ibn Kasīir, when interpreting the term tazkiyah, often used the meaning of being holy and clean rather than others, such as praising himself, feeling holy, being better, worshiping, and doing șäli amal. Sayyid Quṭb defines the term tazkiyah in four meanings: clean, pure, self-praise, and maintaining honor and being better. Meanwhile, Hamka chose the meaning of clean more than others when interpreting the term tazkiyah. It is in line with Al-Zuhaylī, who means more tazkiyah with the meaning of cleansing than others, such as purifying, almadh, and better. As for the Qurais Shihab in interpreting tazkiyah, he tends to use more holy and clean meanings than others, such as the better meaning in Q.S. Al-Kahfi: 19 and praising himself in QS. Al-Najm: 32 and Q.S. An-Nisā ': 49 (Mustakim, 2020).

\section{Spiritualization of Child Education in the Perspective of Qur'anic Sufism}

Munir Mulkan criticizes the weakness of theoretical-conceptual development or even the practice of Islamic education because it does not refer to many primary sources of Islamic teachings, namely al-Qur'an and Sunnah, as the main axis of its development. Thus, it is nothing more than composing, justifying, and modifying the formulation of education in general by being given the "spirit" of the Islamic spirit. Agreeing with him, Halstead stated that at an ideal level, the formulation for the development of Islamic education should be reconstructed from the primary Islamic sources (Mulkan, 2010; Mustakim, 2020).

The spiritualization of education based on Qur'anīc Sufism is the answer to the scientific anxiety above because it tries to reconstruct the meaning of tazkiyah in the Qur'an and its implications from the inspiration of these verses so that it becomes a spiritualization building for Qur'anīc Sufism education.

Qurais Shihab when interpreting Q.S. Al-Syams: 9-10 quotes Al-Biqā'ī's statement that tazkiyah is an effort made seriously by humans so that the sun's heart on him does not experience an 'eclipse' and the 'moon' of his heart. To maintain this condition, a person keeps trying so that the day is not cloudy and the night does not dissolve in the dark. Divine guidance is like the sun, while the prophet's message is like diuh $\bar{a}$ going up in the length of a pole, 'irfän (holy knowledge) is like the day, the guardianship of the moon. Meanwhile, the night is like the 'absence' of calm if it is neglected from żikir, neglected of ilähi guidance, turning away from prophetic guidance and the guidance of ulamā in implementing the teachings of Allah (Shihab, 2011). 
Mustakim, Rouzi \& Tumin | Spiritualization of Child Education in the Qur'anic Sufism Perspective in the Covid-19 Era

Humans have the basic potential of "freedom" in choosing good and bad, as Allah said in QS. Ash-Shams: 8-10 and Q.S. Al-A'lā: 14. Thus, a prophetic treatise came intending to educate the basic human character always to be good and devout. If someone can consistently care for the potential of goodness, he is

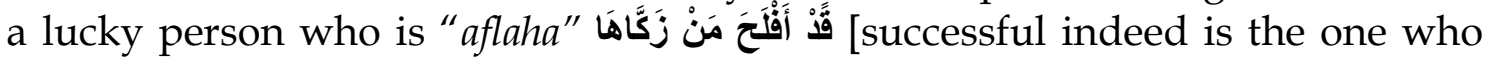
purifies their soul] (Q.S. Asy-syams: 9). Spiritualization through the process of cleansing resources in the form of boon owned is very beneficial for himself both in the world and in the hereafter in the form of multiplying rewards, especially achieving His riḍha (Shihab, 2011; Quṭb, 2000; Ar-razy, 1420; Kasīir, 1419).

On the other hand, when humans ignore spiritualization through tazkiyatun nafs and even tend to prioritize lust to pollute them with immoral acts, do what God forbids, and do detestable and ugly things to dominate their daily

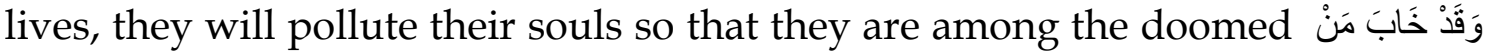
[سَّاهَا [and doomed is the one who corrupts it!] (Q.S. Ash-Shams: 10). Therefore, the human's character and fitriyah ilhamiyah's potential must be directed to always be on the good path through guidance, mentoring, and being developed optimally. All these steps can be done through education, and it is necessary to spiritualize education so that it is more animating and characterizing in everyday life.

According to Mustakim, who reconstructed the spiritualization from Sa 'id Hawwa and Mughni's explanation, a person's zühir condition is greatly influenced by one's mental state. When a person is clean, his heart will always keep the soul pure; everything that comes out from him is good. Spiritualization is 'identical' to inner deeds and has implications for one's zāhiriyah behavior (Mustakim, 2020; Ghazali, 2014; Zainol, 2019). Meanwhile, Qurais Shihab called it a potential virtue that will always give birth to positive energy to always lead to goodness in everyday life (Shihab, 2011; Suud, F. M., Gaffar, A., Rouzi, K. S., \& Chaer, M. T. 2020).

Furthermore, the Qurais Shihab explained that one's potential for "goodness" predominates over negative tendencies. Therefore, Allah gives priority to 'aflaha,' lucky over those who are losers, because they do not maintain their souls' cleanliness and purity, as it is said in Q.S. As-Shams: 8-9. Besides, Sayyid Quṭ stated that positive energy and negative energy are balanced, meaning that they have the same position; a person has an equal proportion of positive and negative "energy." Thus, the risalah nabawiyah [prophetic treatises] came as wasilah to direct, hone, awaken, and sharpen the 'intuition' of fitrah ilhamiyah consistent in virtue and goodness and avoid badness and anything that pollutes the soul. According to the author, this process can be understood as a spiritual cultivation process (Mustakim, 2020).

The spiritualization technique was proposed by Fotos and Susanto as an energizing process. It is in line with what Sayyid Qutb said that the process of animating perceptions, views, and characters will be easily realized if every step and process of development is always goal-oriented and makes them unified in 
Mustakim, Rouzi \& Tumin | Spiritualization of Child Education in the Qur'anic Sufism Perspective in the Covid-19 Era

everyday life so that they become characters/personalities in everyday life. To maintain this challenging process, prophetic treatises and guidance for successors are necessary (Mustakim, 2020).

In the book Qur'anic spiritualization (2020), Mustakim explains Sa'īd Hawwa's thoughts in his book entitled tazkiyatun nafs translated into the Indonesian version entitled "mensucikan jiwa konsep tazkiyatun-nafs terpadu intisari ihya'úlumuddin Al-Gazali [purifying the soul of the concept of integrated tazkiyatun-nafs the essence of Al-Gazali's ihya'úlumuddin" published by the robbani press in 1995. In this book, Sa 'īd Hawwa tried to reconstruct al-Gazali's thought in the book ihya'úlumuddin that in order to achieve the ability to accomplish the true meaning of meaningfulness, a spiritualization wasāil is needed as shown in the following figure.

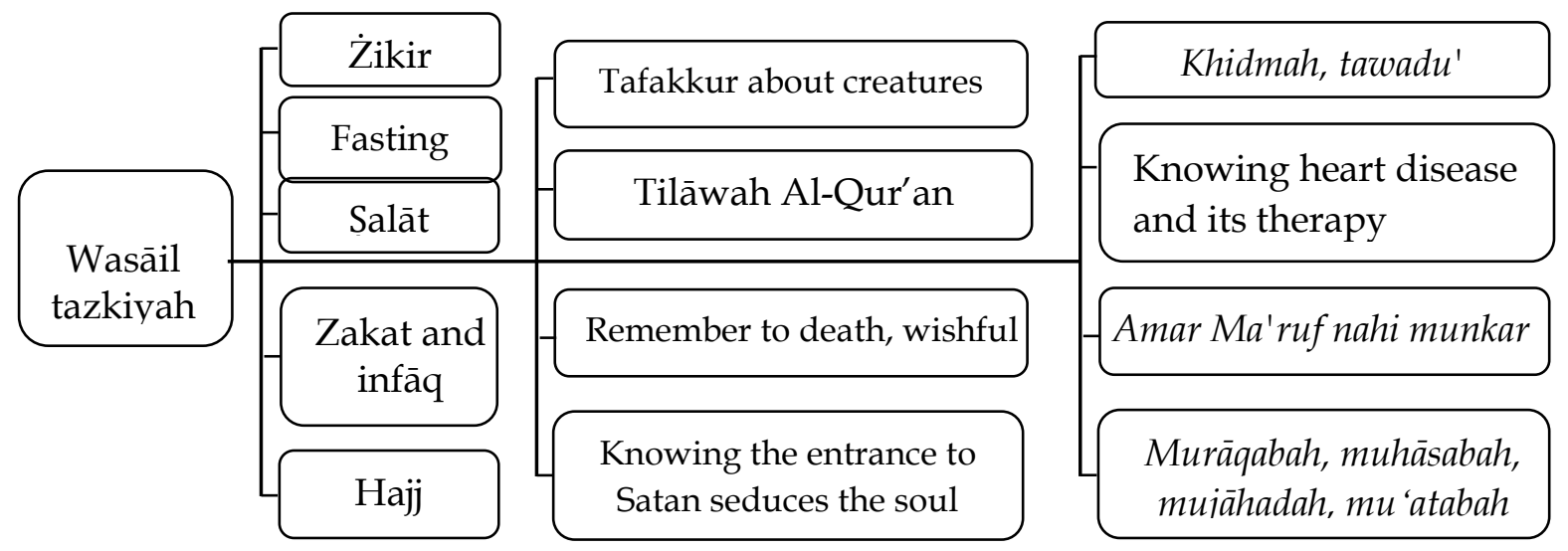

Figure 1

Wasāil Tazkiyah according to Sa 'īd Hawwa as illustrated in the book of Qur'anic spiritualization (Mustakim, 2020)

Wasāil tazkiyah means a medium of realizing tazkiyah as the main sign of spiritualization. If it is drawn into education, there is an understanding that the education spiritualization based on Qur'anic Sufism is a reconstruction of the tazkiyah's meaning and wasail in various education's components: teachers, learning methods, student characteristics, and others.

The values of spiritualization ideals are integrity, humility, honesty (Suud, F. 2017), motivation to unite in diversity, and integrating IQ-EQ-SQ intelligence: intellectual intelligence, emotional intelligence, and spiritual intelligence (Gani, 2019; Grece et al., 2016; Widayati et al., 2019).The education spiritualization of Qur'anīc Sufism is a kinesthetic performance, where the educational process must lead students to reach the highest degree as believers. Spiritualization of education without being based on faith will only lead to 'emptiness.' Thus, the main goal of education spiritualization is to reach the "peak" of human existence, optimal human potential, and the creation of self-awareness.

The description of the education spiritualization concept based on the Qur'anic Sufism above leads to an understanding that education spiritualization is necessary. Moreover, the global era is full of information disclosure and 
Mustakim, Rouzi \& Tumin | Spiritualization of Child Education in the Qur'anic Sufism Perspective in the Covid-19 Era

advanced technological facilities, in which if people do not have a "filter" personality, it will only lead to an arid life. Moreover, from the end of the first quarter of 2020, entering the second quarter until now, the Indonesian nation, in particular, is facing the COVID-19 pandemic, which 'seems' to no end. There are many changes to go through, including in the field of education; school to lectures is conducted through online media, namely learning from home (BDR).

It is a new "normal," less popular before, that forces a phenomenon of many children at home and learning from home via internet devices to "go online" with the parents' assistance at home (Rouzi et al., 2020). This new phenomenon can be an opportunity for parents to educate and assist their children's learning, as is the implementation of 'al-umm madrasatul' ula [parents as primary educators for their children]. However, on the other hand, if it is not done well, it will potentially be bad for the child's education.

Spiritualization of education can be carried out through a process of internalization through the inspiration of Sufism, such as dhikr and tafakur. Dhikr can be interpreted as an effort to remember the Creator by always mentioning His name. In the education of children in the family, it should be decorated with the remembrance of the Creator. Children must be introduced to God from an early age. By remembering Allah a lot, the child's personality will get better. The process of remembering Allah can be reconstructed into an effort to care for the spiritualization process.

The output of the spiritualization process is the realization of someone with a strong personality who can maintain a balance of life between worldly orientation and ukhrowi. If it is drawn into children's education, the spiritualization of education is an effort to bring children closer to God and have Islamic characteristics and personality. Moreover, in a time of the growing pandemic, spiritual provisions must be instilled from an early age.

As the prominent educators in families during the COVID-19 pandemic, parents have the broadest opportunity to accompany their children. Hence, the habituation of wasail tazkiyah as the central conception of education spiritualization, as previously mentioned, is a necessity. The balance of life and spirituality can be considered as a solution to the freedom of access to information media, which is easy to find in today's global era.

Ideally, in addition to accompanying their children in education at home, parents, who currently have a more significant portion, should take advantage of this good opportunity for character building desired by them, in which the children were entrusted to educational institutions so far. Parents are expected to become mu'allim [teachers] for their children, a family mobilizer in the educational process 'at home', so that they are referred to as muharrik, namely the main mover driving the education process at home and as a muzakky, namely the guardian of the spiritual side and enthusiasm, a motivator, and ensures that their children's religious education can be carried out and developed well in the 
Mustakim, Rouzi \& Tumin | Spiritualization of Child Education in the Qur'anic Sufism Perspective in the Covid-19 Era

process. Especially during this pandemic, parents become the main companion in the education process when children learn from home.

The COVID-19 pandemic ushered in a challenge and opportunity for children's education. Therefore, if it is not done correctly, then it is a significant loss for parents as madrasatul ula for their children to maintain, care for, and ensure that their child's growth and development align with their expectations. The spiritualization of children's education with the perspective of Qur'anic Sufism is an integration of three theologies in religion, as proposed by Barbour in 2000, which scientists in Indonesia have widely studied: theology of revelation, natural theology, and religious experience (Anna, 2018; Santi, 2018; Waston, 2014).

\section{CONCLUSION}

Spiritualization of children's education is a necessity. If it is not done well, there is an immense potential that it will only "stop" in formalism alone, not achieve the substance. This study's results confirm Barbour's (2000) theory that a person's diversity comes from the theology of revelation, natural theology, and religious practice. Therefore, the spiritualization of children's education needs to be continuously pursued. This finding strengthens the opinion about the importance of family education. This paper has only reached the urgency of the spiritualization of children's education in the perspective of Qur'anic Sufism. Like a house, it has only arrived at the leading to the entrance level. Therefore, the authors hope that there will be further research or studies to develop the spiritualization of children's education to make the children's education process more meaningful and up to the substance, not just material-oriented.

\section{REFERENCES}

Abdullah, R., \& Saiful, I. (2019). Pendidikan karakter dalam tafsir almisbah surat alisra' ayat 23-24 dan surat luqman ayat 12-19. Jurnal Pendidikan Islam, 3(1), $1-26$

Akbar, A. K. (2015). Hermeneutika versus ta'wil (studi komparatif). Kalimah, 13(1), 45-62. http://dx.doi.org/10.21111/klm.v13i1.278

Anna, D. N. (2018). Metode sains menurut Ian G. Barbour dan sumbangannya terhadap pengkajian islam. Religi Jurnal Studi Agama-Agama, 4(1), 44-65. https:// doi.org/10.14421/rejusta.2018.1401-03

Ar-razy, F. (1420). Mafatihul Ghaib / Tafsir Al-kabir. Dar Ihya' At-turats al-'Araby.

Awaliyah, T., \& Nurzaman, N. (2018). Konsep pendidikan akhlak menurut Sa'id Hawwa. Jurnal Penelitian Pendidikan Islam, 6(1), 23-38. https:// doi.org/10.36667/ippi.v6i1.152

Baqi', M. F. A. (1987). Al-Mu'jam al-Mufakhras li alfaz al-Qur'an al-Karim. Dar al- 
Mustakim, Rouzi \& Tumin | Spiritualization of Child Education in the Qur'anic Sufism Perspective in the Covid-19 Era

Fikr.

Bravo, V. (2018). H.G. Gadamer: Hermeneutics and the processes of comprehension. Utopia y Praxis Latinoamericana. 23(Extra 3), 188-193. https://doi.org/10.5281/zenodo.2427557

Darmawan, D. (2016). Kajian hermeneutika terhadap fenomena dan teks agama. Holistic Al-Hadis, 2(1), 1-24. http:/ / dx.doi.org/10.32678/holistic.v2i1.923

Gani, A. (2019). Pendidikan tasawuf dalam pembentukan kecerdasan spiritual dan akhlakul karimah. Al-Tadzkiyyah: Jurnal Pendidikan Islam, 10(2), 275-286. https://doi.org/10.24042/atjpi.v10i2.5847

Grece, S. Y., \& Latrini, M. Y. (2016). Pengaruh kecerdasan emosional, kecerdasan spiritual, kecerdasan intelektual dan independensi pada kinerja auditor. EJurnal Akuntansi, 16(2), 10034-1062.

Halstead, J. M. (2004). An islamic concept of education. Comparative Education, 40(4), 517-529. https:/ / doi.org/10.1080/0305006042000284510

Hamzah, R., Isa, K. M. D., \& Janor, R. M. (2010). Spiritual education development model. Journal of Islamic and Arabic Education, 2(2), 1-12.

Hanif, M. (2018). Hermeneutika Hans-Georg Gadamer dan signifikansinya terhadap penafsiran Al-Qur'an. Maghza: Jurnal Ilmu Al-Qur'an Dan Tafsir, 2(1), 93-108. https://doi.org/10.24090/maghza.v2i1.1546

Hasibuan, A. (2017). Nilai tasawuf dalam al-quran dan hadis restorasi pemikiran dakwah. Hikmah, 11(1), 75-98. https:// doi.org/10.24952/hik.v11i1.709

Herliandry, L. D., Nurhasanah, N., Suban, M. E., \& Kuswanto, H. (2020). Pembelajaran pada masa pandemi Covid-19. JTP - Jurnal Teknologi Pendidikan, 22(1), 65-70. https:// doi.org/10.21009/jtp.v22i1.15286

Herliandry, L. D., Nurhasanah, Suban, M. E., \& Heru, K. (2020). Transformasi media pembelajaran pada masa pandemi Covid-19. Jurnal Teknologi Pendidikan, 22(1), 65-70. https:// doi.org/10.21009/jtp.v22i1.15286

Indriya, I. (2020). Konsep tafakkur dalam alquran dalam menyikapi coronavirus Covid-19. SALAM: Jurnal Sosial dan Budaya Syar-i, 7(3). https://doi.org/10.15408/sjsbs.v7i3.15050

Ilmi, Z., Darma, D. C., \& Azis, M. (2020). Independence in learning, education management, and industry 4.0: Habitat Indonesia during Covid-19. Journal of Anthropology of Sport and Physical Education, 4(4), 63-66. http://dx.doi.org/10.26773/jaspe.201010

Irawan, R. (2020). Metode kontekstual penafsiran al-qur'an perspektif Fazlur Rahman. Al-Dzikra: Jurnal Studi Ilmu Al-Qur'an Dan Al-Hadits, 13(2), 171-194. https://doi.org/10.24042/al-dzikra.v13i2.4164

Jannah, A. R., Jatimi, A., Heru, M. J. A., Munir, Z., \& Rahman, H. F. (2020). Kecemasan pasien Covid-19: A systematic review. Jurnal Penelitian 
Mustakim, Rouzi \& Tumin | Spiritualization of Child Education in the Qur'anic Sufism Perspective in the Covid-19 Era

\section{Kesehatan, 11, 33-37. http:// dx.doi.org/10.33846/sf11nk406}

Kamil, I. (2020). Mendikbud Nadiem: 94 Persen Siswa Masih Akan Belajar dari Rumah. Kompas.Com.

Kannan, S., Shaik Syed Ali, P., Sheeza, A., \& Hemalatha, K. (2020). Covid-19 (Novel Coronavirus 2019) - recent trends. European Review for Medical and Pharmacological Sciences, 2006-2011. https://doi.org/10.26355/eurrev_202002_20378

Kasīir, I. (1419). Tafsir al-Qur'an al-'Adzim. Dar al-Kitab al- ‘ Ilmiyah.

Lailiyah, I., \& Ridlwan, B. (2020). Peran wanita karir dalam pendidikan islam. $\begin{array}{llll}\text { AL-MISBAH } & \text { (Jurnal Islamic Studies), } & \text { 8(2), } & \text { 74-78. }\end{array}$ https://doi.org/10.26555/al-misbah.v8i2.1151

Momtazmanesh, S., Ochs, H. D., Uddin, L. Q., Perc, M., Routes, J. M., Vieira, D. N., Al-Herz, W., Baris, S., Prando, C., Rosivall, L., Abdul Latiff, A. H., Ulrichs, T., Roudenok, V., Aldave Becerra, J. C., Salunke, D. B., Goudouris, E., Condino-Neto, A., Stashchak, A., Kryvenko, O., Rezaei, N. (2020). All together to fight Covid-19. The American Journal of Tropical Medicine and Hygiene, 102(6), 1181-1183. https://doi.org/10.4269/ajtmh.20-0281

Mufaziah, E., \& Fauziah, P. (2020). Kendala orang tua dalam mendidik anak usia dini pada saat pandemi Covid 19. Jurnal Obsesi : Jurnal Pendidikan Anak Usia Dini, 5(2), 1045-1051. https://doi.org/10.31004/obsesi.v5i2.746

Muh. Mustakim, Syamsul Arifin, Moh Nurhakim, A. I. (2020). Spiritualisasi Pendidikan Qur'ani. Pasific Press.

Muhtadi. (2017). Peran orang tua terhadap pembinaan akhlak anak dalam perspektif pendidikan islam. Sumbula: Jurnal Studi Keagamaan, Sosial Dan Budaya, 2(2), 653-669

Nafisah, F. T., \& Zafi, A. A. (2020). Model pendidikan karakter berbasis keluarga perspektif islam di tengah pendemi Covid-19. Ta'allum: Jurnal Pendidikan Islam, 8(1), 1-20. https:// doi.org/10.21274/taalum.2020.8.1.1-20

Nor, M. R. M., \& Malim, M. (2014). Revisiting islamic education: The case of Indonesia. Journal for Multicultural Education, 8(4), 261-276. https:// doi.org/10.1108/JME-05-2014-0019

Norasid, M. A., \& Abdullah, M. (2019). Gagasan pembangunan modal insan rabbani oleh Sa'îd Ḥawwā dalam al-Asās fỉ al-Tafsīr: Ke arah pemerkasaan kader dakwah. Journal of Usuluddin, 47, 25-48. https://doi.org/10.22452/usuluddin.sp2019no1.2

Parhan, M. (2020). Aktualisasi peran ibu sebagai madrasah pertama dan utama bagi anak di era 4.0. JMIE (Journal of Madrasah Ibtidaiyah Education), 4(2), 157174. https:// doi.org/10.32934/jmie.v4i2.193

Pavone, I. R. (2020). La pandemia globale di covid-19: riflessioni sul ruolo 
Mustakim, Rouzi \& Tumin | Spiritualization of Child Education in the Qur'anic Sufism Perspective in the Covid-19 Era

dell'oms. BioLaw Journal, 1S, 459-482. http://dx.doi.org/10.15168/22844503-603

Quțb, S. (2000). Tafsir fi Zilali al-Qur'an. Gema Insani Press.

Rahman, S. M. H. S. A. (2017). Tazkiyah al-nafs menurut ahli tasawuf. Jurnal Qalbu, 1(5).

Rohman, A. (2020). Implementasi teori pembelajaran blended learning dalam menyeimbangkan kapabilitas belajar pada era digital (Studi Kasus di Prodi PAI Universitas Alma Ata Yogyakarta). An-Nuha: Jurnal Kajian Islam, Pendidikan, Budaya Dan Sosial. https://doi.org/10.36835/annuha.v7i1.343

Rouzi, K. S., Afifah, N., Hendrianto, C., \& Desmita, D. (2020). Establishing an islamic learning habituation through the prophets' parenting styles in the new normal era. International Journal of Islamic Educational Psychology, 1(2), 101-111. https://doi.org/10.18196/ijiep.v1i2.9638

Santi, S. (2018). Relasi agama dan sains menurut Seyyed Hossein Nasr dan Ian G Barbour. Prosiding Konferensi Integrasi Interkoneksi Islam Dan Sains.

Shihab, M. Q. (2011). Tafsir Al-Misbah: pesan, kesan dan keserasian Al-Qur'an. Penerbit Lentera Hati.

Siahaan, M. (2020). Dampak pandemi Covid-19 terhadap dunia pendidikan. Jurnal Kajian Ilmiah, 1(1), 73 - 80. https:// doi.org/10.31599/jki.v1i1.265

Suharini, E., Kurniawan, E., \& Ichsan, I. Z. (2020). Disaster mitigation education in the COVID-19 pandemic: A case study in Indonesia. Sustainability, 13(6), 292-298. https:// doi.org/10.1089/sus.2020.0053

Suhendro, E. (2020). Strategi pembelajaran pendidikan anak usia dini di masa pandemi Covid-19. Golden Age: Jurnal Ilmiah Tumbuh Kembang Anak Usia Dini, 5(3), 133-140. https:// doi.org/10.14421/iga.2020.53-05

Sumantyo, F. D. S. (2020). Pendidikan Tinggi di masa dan pasca Covid-19. Jurnal Kajian Ilmiah. https:// doi.org/10.31599/jki.v1i1.266

Suud, F. M., Gaffar, A., Rouzi, K. S., \& Chaer, M. T. (2020). The role of islamic counselling in pandemic Covid 19: a conceptual study for developing positive emotion of parents and children. KONSELING RELIGI Jurnal Bimbingan Konseling Islam, 11(1), 18-35. http://dx.doi.org/10.21043/kr.v11i1.7705

Tarmizi, T. (2017). Pendidikan rohani dalam al-Quran. Fitrah:Jurnal Kajian IlmuIlmu Keislaman, 2(2), 123. https://doi.org/10.24952/ fitrah.v2i2.477

Wardani. (2017). Metodologi tafsiral-qur'an di indonesia.

Waston. (2014). Hubungan sains dan agama: refleksi filosofis atas pemikiran Ian G. Barbour. PROFETIKA, Jurnal Studi Islam, 15(1), 76-89.

Widayati, N., \& Ristiyana, R. (2019). Pengaruh kecerdasan emosional, kecerdasan spiritual, kecerdasan sosial, dan perilaku belajar terhadap tingkat 
Mustakim, Rouzi \& Tumin | Spiritualization of Child Education in the Qur'anic Sufism Perspective in the Covid-19 Era

pemahaman akuntansi. Jurnal Penelitian Dan Karya Ilmiah, 19(2), 194-209. https:// doi.org/10.33592/pelita.vol19.iss2.121

Wisri, W., \& Mughni, A. (2016). Paradigma dasar fenomenologis, hermeneutika dan teori kritis. Lisan Al-Hal: Jurnal Pengembangan Pemikiran Dan Kebudayaan, 10(1), 5-20. https:// doi.org/10.35316/lisanalhal.v10i1.109

Yasin, A. F. (2018). Wanita karir dan problem pendidikan anak. Ulul Albab Jurnal Studi Islam, 3(2), 105-120. https:/ / doi.org/10.18860/ua.v3i2.6110

Zainol, N. Z. N. (2019). Sumbangan Sheikh Sa'id Hawwa (1935-1989): Sorotan awal proses tazkiyah al-nafs sebagai wadah pembersihan jiwa. Teraju, 1(02), 73-78. https:// doi.org/10.35961/teraju.v1i02.61 